\title{
Detection of Plasma Level of Amyloid Protein Precursor in Children and Adolescent with Down Syndrome
}

\author{
FATMA AL ZAHRAA N.M. SHERAI, M.Sc.*; MOHAMMED A. ROWISHA, M.D.*; \\ MAALY M. MABROUK, M.D.** and HEBA E. DAWOUD, M.D.* \\ The Departments of Pediatrics* and Clinical Pathology**, Faculty of Medicine, Tanta University
}

\begin{abstract}
Background: Down syndrome (DS, Trisomy 21) is a genetic disease resulting from the presence of all or part of an extra 21 chromosome and may affect the function of any organ and system. It is the most common chromosomal abnormality, with a frequency of 1:800 to 1:1000 births. In Egypt, it varies between 1 in 555 in one study to 1 in 770 in another. Amyloid Precursor Protein (APP) is a membrane protein concentrated in the synapses of neurons. APP proteolysis generates beta amyloid (A P), which forms amyloid plaques found in the brains of Alzheimer's disease patients. In DS, there is increase in production of (A P), so children and adolescents are more susceptible for dementia and Alzheimer's disease.
\end{abstract}

Aim of Study: It was to compare plasma Amyloid protein (AP) level in children suffering from DS with its level in the controls and correlation between (A P) level and Intelligent Quotient (IQ) of the studied subjects.

Patients and MethoDS: This study was carried out on 40 Egyptian children divided into: 20 children with DS with age range (3-16 years) under follow-up at Genetics Unit of Pediatric Department Tanta University Hospital and 20 healthy children with normal karyotyping matched for sex and age. All patients and controls were subjected to complete history taking, clinical examination, and laboratory investigations including (karyotyping, cholesterol \& triglycerides level, thyroid function test, random blood sugar, Intelligent Quotient (IQ), and beta amyloid protein serum level.

Results: Serum Beta amyloid protein level was significantly higher in children and adolescents with DS in comparison with healthy control.

Conclusion: We concluded that serum Beta amyloid protein level was significantly higher in children and adolescents with DS in comparison with healthy control. We also concluded that there was a significant positive correlation between serum beta amyloid protein level and age of children and adolescents with Down syndrome and there is no correlation between AP and IQ.

Key WorDS: Down syndrome - Serum Beta amyloid protein (A P) by ELISA.

Correspondence to: Dr. Fatma Al-Zahraa N.M. Sherai, The Department of Pediatric, Faculty of Medicine, Tanta University

\section{Introduction}

DOWN Syndrome (DS, Trisomy 21) is a genetic condition caused by the presence of all or part of a third copy of chromosome 21 [1]. It is one of the most frequent causes of mental retardation occurring in one of 733 live birth in United states of America (USA). It is typically associated with physical growth delays, mild to moderate intellectual disability and characteristic features (low muscle tone, single deep crease across the palm of hand called Simian crease and upward slanting of eyes) [3].

Amyloid Precursor Protein (APP) is an integral membrane protein expressed in many tissues and concentrated in the synapses of neurons [4] Beta amyloid protein (AP) is produced by the sequential cleavage of APP by beta-secretase [5] which has now been identified as beta-site amyloid precursor protein cleaving enzyme (BACE). The gene for BACE is also located on chromosome 21 in $\mathrm{DS}$ and may contribute to increased $\mathrm{AB}$ production [6].

One study showed that increased levels of AP were found in brain extracts of children with DS but not in controls [7]. The most likely explanation for the increased A P levels in DS brain extracts is the presence of an extra copy of the APP gene, located on chromosome 21 , which may lead to the over production of AP proteins in brain and Plasma [8-10].

Individuals with Down Syndrome (DS) develop Alzheimer's Disease (AD) pathology in a progressive age dependent manner [11-13] and as such are at high risk for the development of dementia [12]

Dementia is a clinical term that refers to the development of progressive cognitive deterioration 
associated with an inability to perform normal activities of daily living [14].

When dementia affects the young, there is usually a single pathologic process present on autopsy such as the neuritic plaques and neurofibrillary tangles [15]. The core protein of this neuritic plaques is amyloid 0 (AR) protein which is proteolytically derived from Amyloid Precursor Protein (APP) [16].

\section{Patients and MethoDS}

This observational case control study was carried out on 40 Egyptian children who were divided into (1): Patient group, twenty children with Down syndrome with age range (3-16 years) under followup at Genetic Unit of Pediatrics Department Tanta University Hospital during the period from February 2017 to August 2018. Diagnosis of Down syndrome was based on karyotyping and clinical examination. (2) Control group, twenty healthy children with normal karyotyping matched for sex and age. Each group was classified into three subgroups according to age: Group 1 (4-5 years), Group 2 (6-10 years) and Group 3 (11-15 years).

\section{Inclusion criteria:}

1- Children with Down syndrome confirmed by Karyotyping.

2- Children with age range (3-16 years).

\section{Exclusion criteria:}

Children with other chromosomal anomalies $\&$ Down syndrome children with history of perinatal insult as (perinatal asphyxia, hyperbilirubinemia, trauma, abnormal thyroid function, Down syndrome with diabetes mellitus or obesity, seizures).

Both patients and controls were subjected to complete history taking, full clinical examination searching for dysmorphic features characteristic to Down syndrome, Intelligent Quotient (IQ) for both patients and controls, laboratory investigations including karyotyping, cholesterol \& triglycerides level, thyroid function test, random blood sugar and research investigation, beta amyloid protein serum level.

Written informed consent was obtained from the parents of all subjects of the study. The study was started after the approval by Ethics Committee of Faculty of Medicine, Tanta University. When we took any sample we may introduce infection to the patient and to minimize this risk the sample was taken under complete aseptic condition. There is no other unexpected risks appeared during the course of the research. We put code number to every patient symbol to the name address that was kept in a special file. We hide the patient name when we use the research. We used the results of the research only in scientific aim and did not use it in any other aims.

The blood was allowed to clot at room temperature from 10-20mins. Centrifugation was done for 20min. at the speed of 2000-3000r.p.m. supernatant was removed by means of clean dry tube for determination of plasma beta amyloid protein (AR ) level by ELISA kit which is based on the principle of double-antibody sandwich technique to detect Human (AR) used only for research purposes. Specimen was kept in $\left(-20^{\circ} \mathrm{C}\right)$ and repeated freeze-thaw cycles were avoided. This ELISA kit is for in-vitro diagnostic use.

Statistical presentation and analysis of the present study was conducted using the mean, standard deviation, student $t$-test, Chi-square, F-test (ANOVA), Pearson coefficient, Spearman coefficient, paired $t$-test by IBM SPSS software package version 20. (Armonk, NY: IBM Corp) [17] with $p$ $<0.05$ means significance.

\section{Results}

This study was conducted on 20 cases with Down syndrome and 20 healthy controls, both patients and control were cross matched for age and sex.

\section{Demographic data:}

Tables $(1,2)$ and Figs. $(1,2)$ present the demographics of the case control study population as regard age, sex, residence. They show no statistically significant difference as regard age, sex or residence between patients and controls ( $p$-value $>0.05$ ).

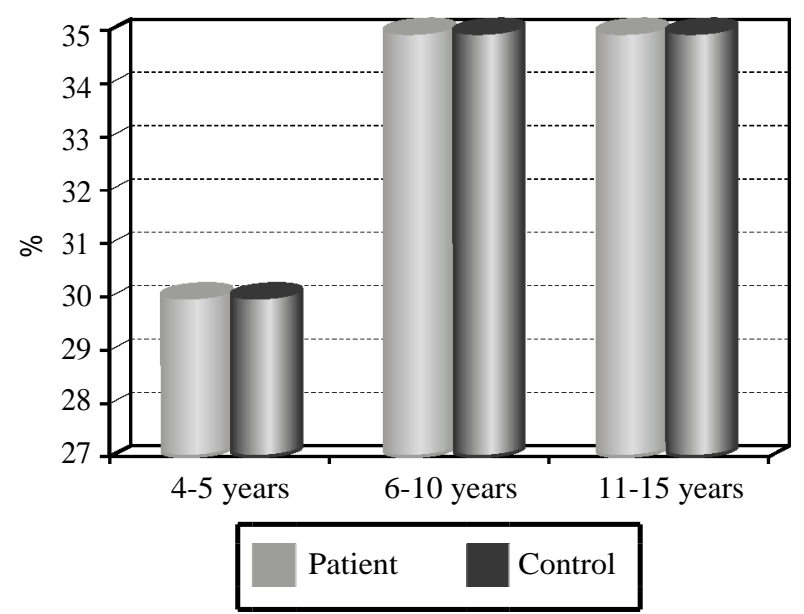

Fig. (1): Classification of studied groups according to age. 


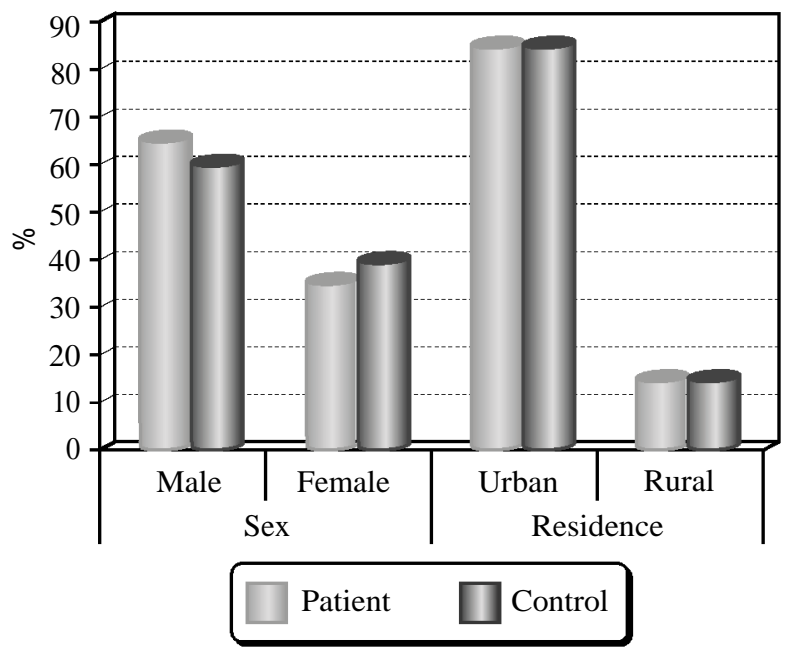

Fig. (2): Sex, residence of studied groups.

Table (1): Classification of studied groups according to age.

\begin{tabular}{|c|c|c|c|c|c|c|c|c|}
\hline \multirow{3}{*}{ Age groups } & \multicolumn{6}{|c|}{ Groups } & \multicolumn{2}{|c|}{ Chi-Square } \\
\hline & \multicolumn{2}{|c|}{ Patient } & \multicolumn{2}{|c|}{ Control } & \multicolumn{2}{|c|}{ Total } & \multirow{2}{*}{$x^{2}$} & \multirow{2}{*}{$\begin{array}{c}p- \\
\text { value }\end{array}$} \\
\hline & $\mathrm{N}$ & $\%$ & $\mathrm{~N}$ & $\%$ & $\mathrm{~N}$ & $\%$ & & \\
\hline $4-5$ years & 6 & 30.00 & 6 & 30.00 & 12 & 30.00 & 0.000 & 1.000 \\
\hline $6-10$ years & 7 & 35.00 & 7 & 35.00 & 14 & 35.00 & & \\
\hline $11-15$ years & 7 & 35.00 & 7 & 35.00 & 14 & 35.00 & & \\
\hline Total & 20 & 100.00 & 20 & 100.00 & 40 & 100.00 & & \\
\hline
\end{tabular}

Table (2): Age, sex, residence of studied groups.

\begin{tabular}{|c|c|c|c|c|c|c|}
\hline & \multicolumn{4}{|c|}{ Groups } & \multicolumn{2}{|c|}{$t$-test or Chi-Square } \\
\hline & \multicolumn{2}{|c|}{ Patient } & \multicolumn{2}{|c|}{ Control } & $t$ & $p$-value \\
\hline \multicolumn{7}{|l|}{ Age (years): } \\
\hline Range & \multicolumn{2}{|c|}{$4-15$} & \multicolumn{2}{|c|}{$4-15$} & \multirow[t]{2}{*}{-0.086} & \multirow[t]{2}{*}{0.932} \\
\hline Mean \pm SD & \multicolumn{2}{|c|}{$8.375 \pm 3.674$} & \multicolumn{2}{|c|}{$8.475 \pm 3.680$} & & \\
\hline \multicolumn{7}{|l|}{ Sex: } \\
\hline Male & 13 & 65.00 & 12 & 60.00 & 0.107 & 0.744 \\
\hline Female & 7 & 35.00 & 8 & 40.00 & & \\
\hline \multicolumn{7}{|l|}{ Residence: } \\
\hline Urban & 17 & 85.00 & 17 & 85.00 & 0.000 & 1.000 \\
\hline Rural & 3 & 15.00 & 3 & 15.00 & & \\
\hline
\end{tabular}

History of studied group:

\section{1- Prenatal history:}

Table (3): Prenatal history of studied groups.

\begin{tabular}{|c|c|c|c|c|c|c|c|c|}
\hline \multirow{3}{*}{$\begin{array}{l}\text { Prenatal } \\
\text { history }\end{array}$} & \multicolumn{6}{|c|}{ Groups } & \multicolumn{2}{|c|}{ Chi-Square } \\
\hline & \multicolumn{2}{|c|}{ Patient } & \multicolumn{2}{|c|}{ Control } & \multicolumn{2}{|c|}{ Total } & \multirow{2}{*}{$x^{2}$} & \multirow{2}{*}{$\begin{array}{c}p- \\
\text { value }\end{array}$} \\
\hline & $\mathrm{N}$ & $\%$ & $\mathrm{~N}$ & $\%$ & $\mathrm{~N}$ & $\%$ & & \\
\hline • Negative & 16 & 80.00 & 17 & 85.00 & 33 & 82.50 & 3.030 & 0.553 \\
\hline $\begin{array}{l}\text { - Threatened } \\
\text { abortion }\end{array}$ & 2 & 10.00 & 2 & 10.00 & 4 & 10.00 & & \\
\hline • PROM & 1 & 5.00 & 0 & 0.00 & 1 & 2.50 & & \\
\hline $\begin{array}{l}\text { - Congenital } \\
\text { infection }\end{array}$ & 1 & 5.00 & 0 & 0.00 & 1 & 2.50 & & \\
\hline - Preeclampsia & 0 & 0.00 & 1 & 5.00 & 1 & 2.50 & & \\
\hline Total & 20 & 100.00 & 20 & 100.00 & 40 & 100.00 & & \\
\hline
\end{tabular}

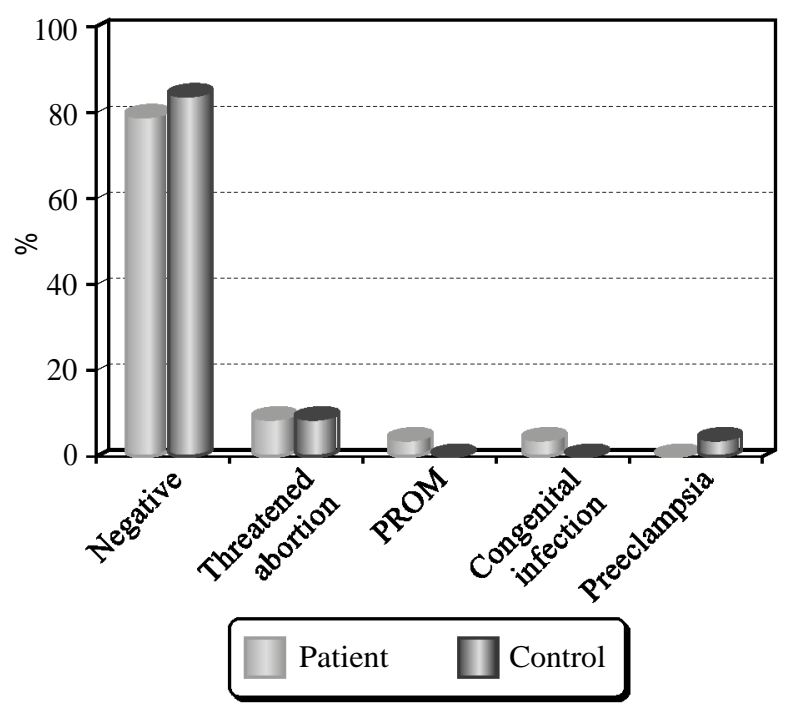

Fig. (3): Prenatal history of studied groups.

Table (3) and Fig.(3) show no statistically significant difference as regard prenatal history (threatened abortion, premature rupture of membrane $\{$ PROM $\}$, congenital infection \& pre-eclampsia) between patients and controls.

\section{2- Natal history (mode of delivery):}

Table (4): Mode of delivery of the studied groups.

\begin{tabular}{|c|c|c|c|c|c|c|c|c|}
\hline \multirow{3}{*}{$\begin{array}{l}\text { Natal } \\
\text { history }\end{array}$} & \multicolumn{6}{|c|}{ Groups } & \multicolumn{2}{|c|}{ Chi-Square } \\
\hline & \multicolumn{2}{|c|}{ Patient } & \multicolumn{2}{|c|}{ Control } & \multicolumn{2}{|c|}{ Total } & \multirow{2}{*}{$x^{2}$} & \multirow{2}{*}{$\begin{array}{c}p- \\
\text { value }\end{array}$} \\
\hline & $\mathrm{N}$ & $\%$ & $\mathrm{~N}$ & $\%$ & $\mathrm{~N}$ & $\%$ & & \\
\hline CS & 11 & 55.00 & 11 & 55.00 & 22 & 55.00 & 0.000 & 1.000 \\
\hline NVD & 9 & 45.00 & 9 & 45.00 & 18 & 45.00 & & \\
\hline Total & 20 & 100.00 & 20 & 100.00 & 40 & 100.00 & & \\
\hline
\end{tabular}

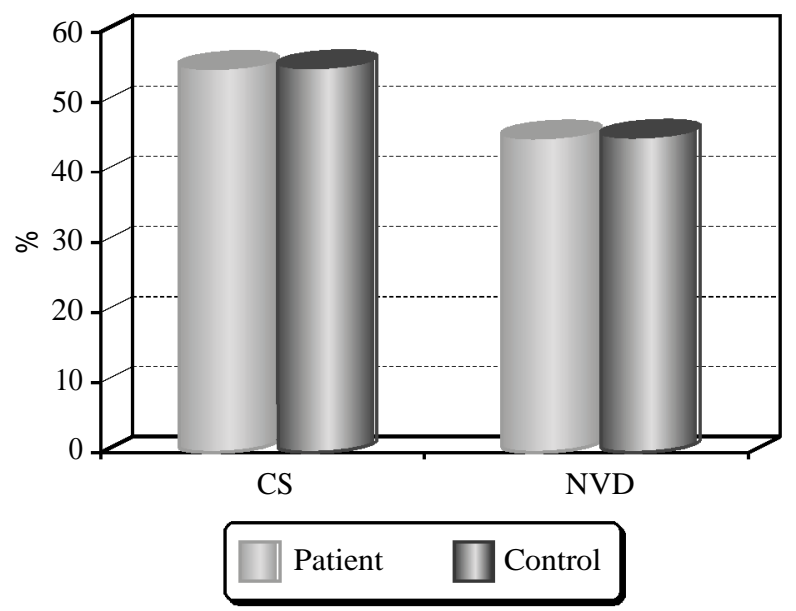

Fig. (4): Natal history of the studied groups.

C.S: Cesarean Section. N ND: Normal Vaginal Delivery.

Table (4) and Fig. (4) show no statistically significant difference as regard natal history (C.S or vaginal delivery) between patients and controls. 


\section{3- Postnatal history:}

Table (5): Postnatal history (incubation/jaundice) of studied groups.

\begin{tabular}{|c|c|c|c|c|c|c|c|c|}
\hline \multirow{3}{*}{$\begin{array}{l}\text { Post natal } \\
\text { history } \\
\text { (incubation } \\
\text { /jaundice) }\end{array}$} & \multicolumn{6}{|c|}{ Groups } & \multicolumn{2}{|c|}{ Chi-Square } \\
\hline & \multicolumn{2}{|c|}{ Patient } & \multicolumn{2}{|c|}{ Control } & \multicolumn{2}{|r|}{ Total } & \multirow{2}{*}{$x^{2}$} & \multirow{2}{*}{$\begin{array}{c}p- \\
\text { valu }\end{array}$} \\
\hline & $\mathrm{N}$ & $\%$ & $\mathrm{~N}$ & $\%$ & $\mathrm{~N}$ & $\%$ & & \\
\hline No & 18 & 90.00 & 19 & 95.00 & 37 & 92.50 & 0.360 & 0.54 \\
\hline Yes & 2 & 10.00 & 1 & 5.0 & 3 & 7.50 & & \\
\hline Total & 20 & 100.00 & 20 & 100.00 & 40 & 100.00 & & \\
\hline
\end{tabular}

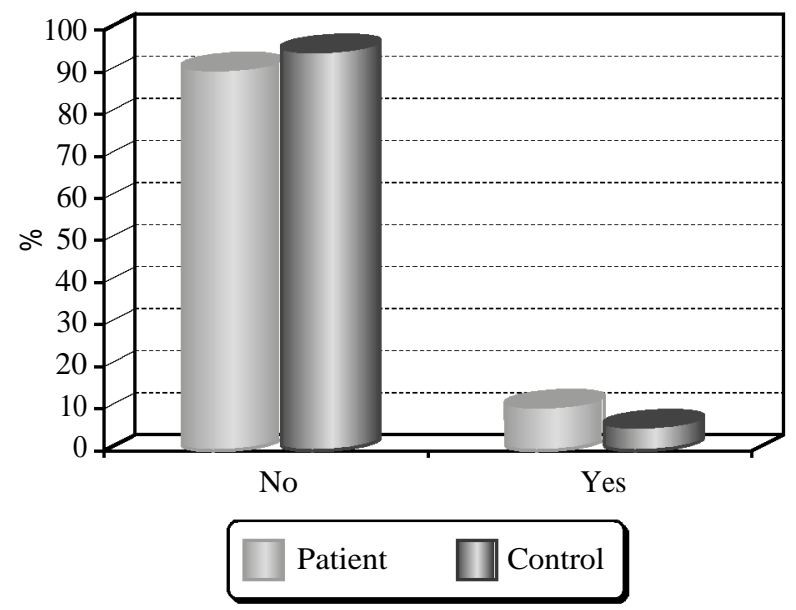

Fig. (5): Postnatal history (incubation/jaundice) of studied groups.

Table (5) and Fig. (5) show no statistically significant difference as regard postnatal history (incubation/jaundice) between patients and controls.

\section{4- Family history:}

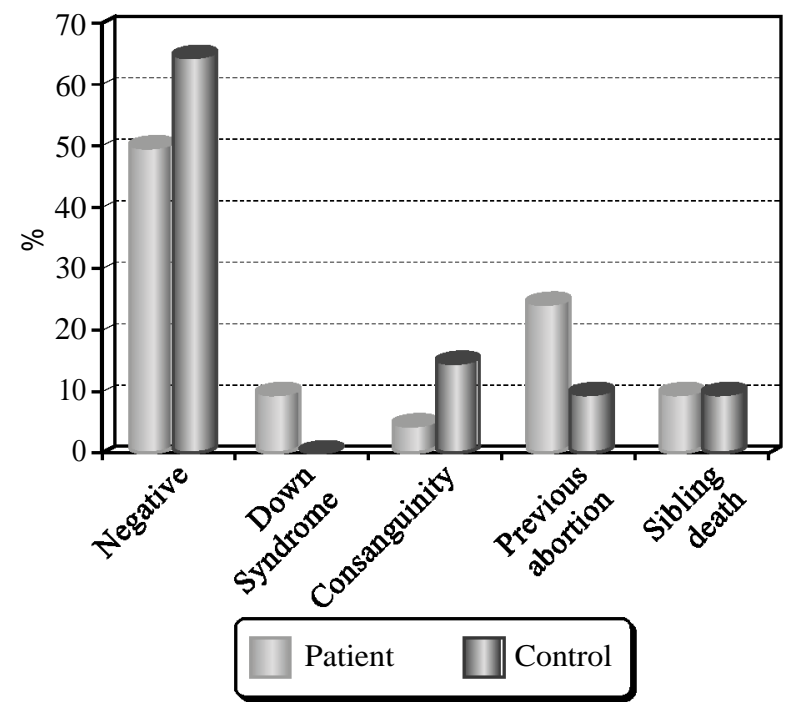

Fig. (6): Family history of studied groups.

Table (6) and Fig. (6) show no statistically significant difference as regard family history (positive consanguinity, Down syndrome cases in the family, previous abortion or sibling death) between patients and controls.

Table (6): Family history of studied groups.

\begin{tabular}{|c|c|c|c|c|c|c|c|c|}
\hline \multirow{3}{*}{ Family history } & \multicolumn{6}{|c|}{ Groups } & \multicolumn{2}{|c|}{ Chi-Square } \\
\hline & \multicolumn{2}{|c|}{ Patient } & \multicolumn{2}{|c|}{ Control } & \multicolumn{2}{|r|}{ Total } & \multirow{2}{*}{$x^{2}$} & \multirow{2}{*}{$\begin{array}{c}p- \\
\text { value }\end{array}$} \\
\hline & $\mathrm{N}$ & $\%$ & $\mathrm{~N}$ & $\%$ & $\mathrm{~N}$ & $\%$ & & \\
\hline Negative & & 50.00 & & 65.00 & 23 & 57.50 & 4.677 & 0.322 \\
\hline Down Syndrome & 2 & 10.00 & 0 & 0.00 & 2 & 5.00 & & \\
\hline Consanguinity & 1 & 5.00 & 3 & 15.00 & 4 & 10.00 & & \\
\hline Previous abortion & 5 & 25.00 & 2 & 10.00 & 7 & 17.50 & & \\
\hline Sibling death & 2 & 10.00 & 2 & 10.00 & 4 & 10.00 & & \\
\hline Total & & 100.00 & & 100.00 & 40 & 100.00 & & \\
\hline
\end{tabular}

Maternal and paternal age of studied groups:

Table (7): Maternal age during pregnancy of studied groups.

\begin{tabular}{|c|c|c|c|c|}
\hline \multirow{2}{*}{$\begin{array}{l}\text { Maternal age } \\
\text { during } \\
\text { pregnancy (years) }\end{array}$} & \multicolumn{2}{|c|}{ Groups } & \multicolumn{2}{|c|}{$t$-test } \\
\hline & Patient & Control & $t$ & $p$-value \\
\hline $\begin{array}{l}\text { Range } \\
\text { Mean } \pm \text { SD }\end{array}$ & $\begin{array}{l}18-43 \\
34.250 \pm 6.980\end{array}$ & $\begin{array}{l}18-30 \\
23.000 \pm 3.309\end{array}$ & 6.513 & $<0.001 *$ \\
\hline
\end{tabular}

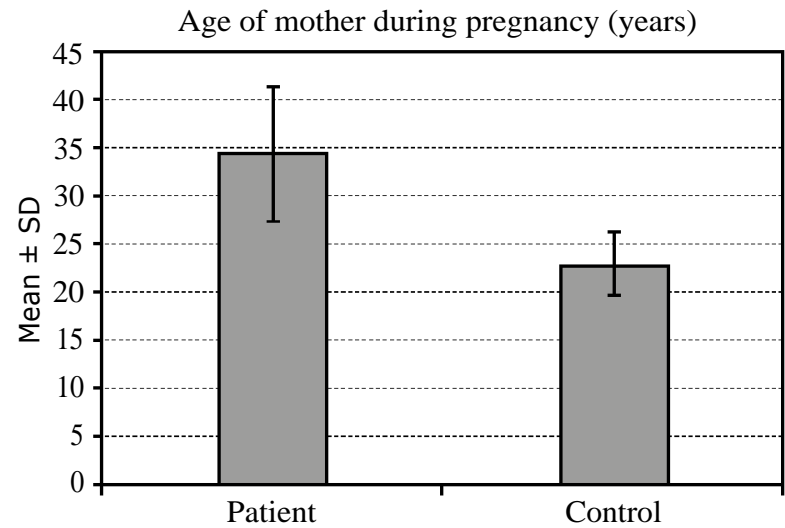

Fig. (7): Maternal age during pregnancy of studied groups.

Table (7) and Fig. (7) show highly significant increase in maternal age of Down syndrome patients more than controls.

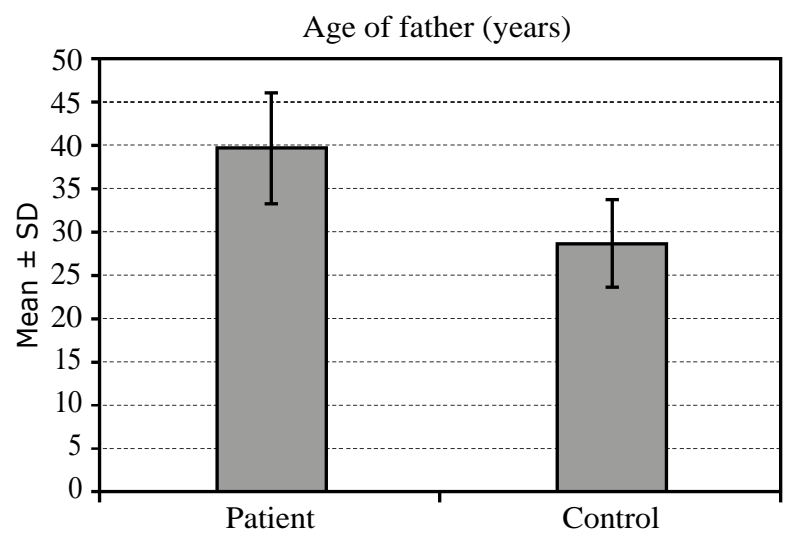

Fig. (8): Paternal age of studied groups. 
Table (8): Paternal age of studied groups.

\begin{tabular}{llllll}
\hline \multirow{2}{*}{$\begin{array}{l}\text { Age of } \\
\text { father (years) }\end{array}$} & \multicolumn{2}{c}{ Groups } & & \multicolumn{2}{c}{$t$-test } \\
\cline { 2 - 3 } \cline { 6 - 7 } & \multicolumn{1}{c}{ Patient } & \multicolumn{1}{c}{ Control } & & $t$ & $p$-value \\
\hline Range & $29-54$ & $20-39$ & & 6.023 & $<0.001 *$ \\
Mean \pm SD & $39.550 \pm 6.329$ & $28.700 \pm 4.985$ & & \\
\hline
\end{tabular}

Table (8) and Fig. (8) show highly significant increase in paternal age of Down syndrome patients more than controls.

\section{Intelligence quotient (IQ) of studied groups:}

Table (9): Intelligence quotient (IQ) of studied groups.

\begin{tabular}{llllll}
\hline \multirow{2}{*}{ IQ $(\%)$} & \multicolumn{2}{c}{ Groups } & & \multicolumn{2}{c}{$t$-test } \\
\cline { 2 - 3 } \cline { 5 - 6 } & \multicolumn{1}{c}{ Patient } & \multicolumn{1}{c}{ Control } & & $t$ & $p$-value \\
\hline Range & $37-64$ & $100-120$ & & -25.251 & $<0.001 *$ \\
Mean \pm SD & $50.000 \pm 7.698$ & $109.650 \pm 7.235$ & & \\
\hline
\end{tabular}

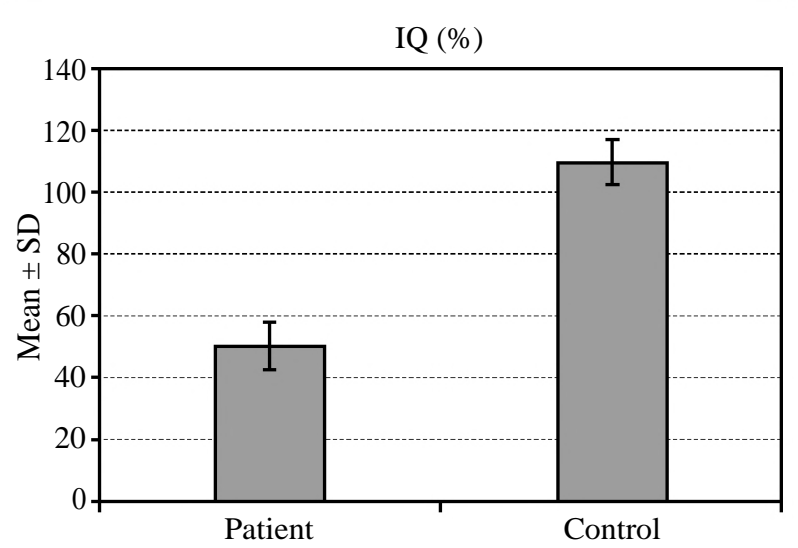

Fig. (9): Intelligence quotient (IQ) of studied groups.

Table (9) and Fig. (9) show highly significant decrease in IQ of Down syndrome patients more than controls.

\section{Serum Beta amyloid protein of studied groups:}

Table (10) and Fig. (10) show that serum Beta amyloid protein level is significantly higher in patients more than controls.

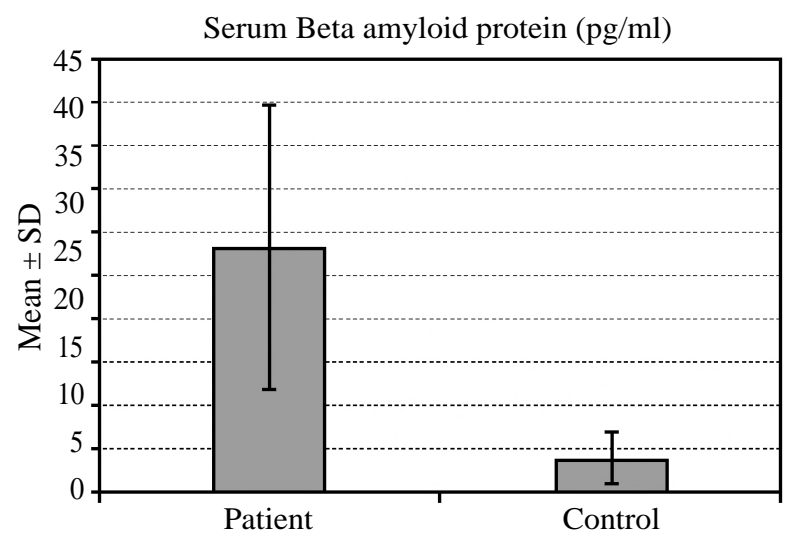

Fig. (10): Serum Beta amyloid protein of studied groups. $\mathrm{Pg} / \mathrm{ml}$ : Picogram/milliliter. SD: Standard Deviation.
Table (10): Serum Beta amyloid protein of studied groups.

\begin{tabular}{llllll}
\hline $\begin{array}{l}\text { Serum Beta } \\
\text { amyloid protein } \\
(\mathrm{pg} / \mathrm{ml})\end{array}$ & \multicolumn{2}{c}{ Groups } & & \multicolumn{2}{c}{$t$-test } \\
\cline { 2 - 3 } \cline { 6 - 7 } & \multicolumn{1}{c}{ Patient } & Control & & $t$ & $p$-value \\
\hline Range & $11.13-90.4$ & $1.09-10$ & & 6.488 & $<0.001 *$ \\
Mean $\pm \mathrm{SD}$ & $28.148 \pm 16.433$ & $3.929 \pm 2.937$ & & \\
\hline
\end{tabular}

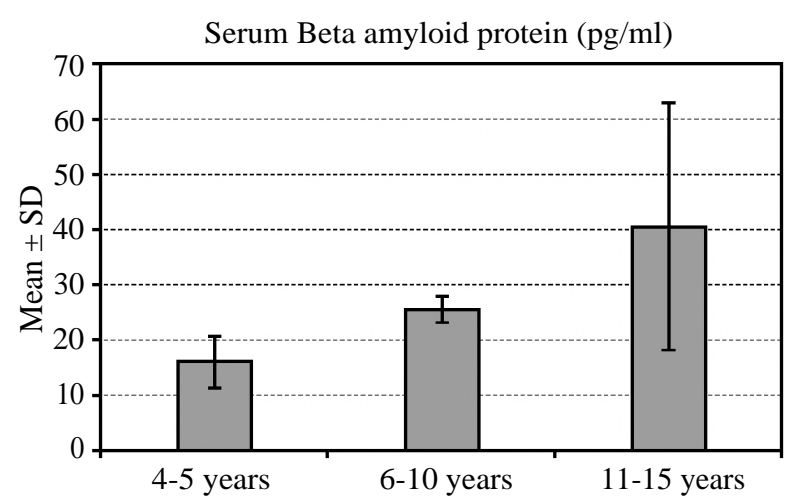

Fig. (11): Relation between serum Beta amyloid protein level and age of the patient groups.

In the patient groups, it showed significant positive correlation between serum Beta amyloid protein levels with increase in age. (With increased age there is increase in serum Beta amyloid protein level).

Table (11): Correlation between Serum Beta amyloid protein level, age and IQ of the patient groups.

\begin{tabular}{llc}
\hline \multicolumn{2}{c}{ Correlations } \\
\hline & \multicolumn{2}{c}{ Serum Beta amyloid protein $(\mathrm{pg} / \mathrm{ml})$} \\
\cline { 2 - 3 } & \multicolumn{1}{c}{$p$-value } \\
\hline Age (years) & 0.498 & $0.026^{*}$ \\
IQ $(\%)$ & 0.378 & 0.101 \\
\hline
\end{tabular}

In the patient groups, it showed:

- Significant positive correlation between age and serum Beta amyloid protein level.

- No significant correlation between IQ and serum Beta amyloid protein level.

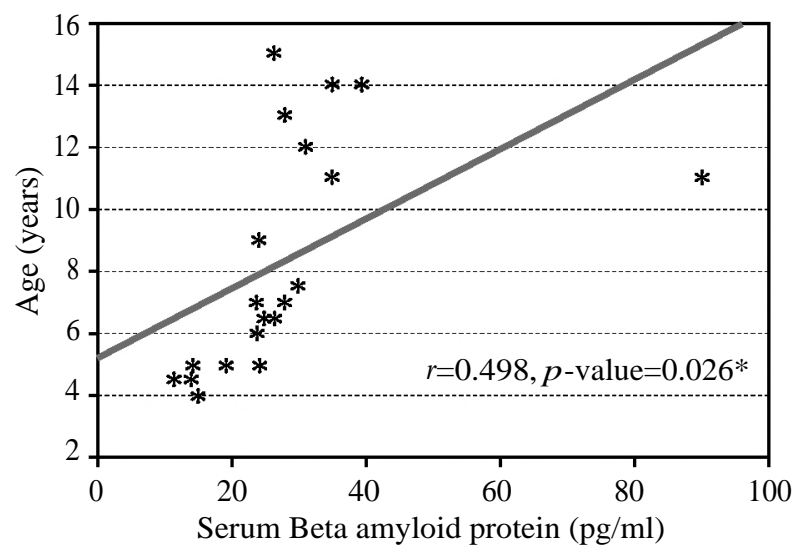

Fig. (12): Correlation between Serum Beta amyloid protein level and age of the patient group. 


\section{Discussion}

Down syndrome (Trisomy 21) is a genetic disease resulting from the presence of all or part of an extra 21 chromosome. The medical consequences of this extra genetic material are highly variable and may affect the function of any organ system [18].

Down syndrome is the most common chromosomal abnormality, with a frequency of one per 800 to one per 1000 births [19]. In Egypt, the incidence varies between 1 in 555 in one study to 1 in 770 in another [20]. DS accounts for about one third of all moderate and severe mental handicaps in school-aged children [19].

Amyloid precursor protein is an integral membrane protein expressed in many tissues and concentrated in the synapses of neurons. Its primary function is not known, though it has been implicated as a regulator of synapse formation, neural plasticity and iron export $[\mathbf{2 1 , 2 2 ]}$.

APP is best known as the precursor molecule whose proteolysis by beta-site amyloid precursor protein cleaving enzyme) BACE) generates beta amyloid (AR) which is a polypeptide containing 37 to 49 amino acid residues, whose amyloid fibrillary form is the primary component of amyloid plaques found in the brains of Alzheimer's disease patients [23].

In DS, two components leading to the increased production of $A R$ are present in triplicate and include APP and BACE. The gene for BACE-2 is also located on chromosome 21 in the DS obligate region and may contribute to increased $A R$ production. However, despite the life-long overexpression of these two proteins, diffuse plaques do not begin to accumulate until individuals are over the age of 30 years (diffuse plaques have been reported in younger individuals but this is not a consistent feature) [24].

This study compared plasma amyloid protein (AR) level in children suffering from down syndrome with its level in the controls \& tryto correlate between (AR) level and Intelligent Quotient (IQ) of the studied subject.

In the present study, there was insignificant difference between patients and controls regarding their age, sex and residence. This matchs with Mehta et al., [25] study which included 35 children and adolescent with DS and 34 healthy controls and showed no significant difference between patients and controls regarding their age, sex and residence.

In the present study, there was statistically significant difference between patients and controls regarding to maternal age, increased maternal age in DS patients than control. This agreed with Diamandopoulos et al., [26] which showed that increased maternal age is the most common risk factor for down syndrome and occurrence of the disorder increases significantly with advancing maternal age. Hussamy et al., [27] found that 53\% of infants with down syndrome were born to women 35 years and older. McNerney et al., [28] showed that the most important risk factor for aneuploidy in humans is the age of the mother. At the maternal age of 20 years, around $0.058 \%$ of live born infants are diagnosed with DS. This increases to $4.12 \%$ at 46 years-a 70-fold increase in incidence. In the majority of cases (65\%), human trisomy 21 is due to errors in maternal meiosis I.

In the present study, there was statistically significant difference between patients and controls regarding to paternal age, showing increased paternal age in DS patients more than control. This agreed with Diamandopoulos et al., [26] who pointed to evidence more that advanced paternal age could also be implicated as a risk factor. Andersen et al., [29] reported that the risk of Down syndrome was increased with increasing paternal age. Ramasamy et al., [30] study said that the extra chromosome 21 is of paternal origin in approximately $10 \%$ of down syndrome cases and advanced paternal age significantly influences the incidence of Down syndrome when the female partner of a couple is $>35$ years old. Andersen et al., [29] who reported that the risk of Down syndrome was increased with increasing paternal age.

But this disagreed with Zigman et al., (2013) [31] who found more that an increased incidence of a birth of an infant with DS was directly related to maternal, but not paternal age.

In the present study, there was statistically significant difference between patients and controls regarding the IQ, decrease IQ in DS patients than control. This agreed with McNerney et al., (2017) [28] found that the severity of intellectual disability in DS patients is typically moderate, with an Intelligent Quotient (IQ) average of 40, (range: 20-70). Grieco et al., (2015) [32] showed that the severity of intellectual disability among individuals with DS falls on a spectrum that ranges from profound to borderline intellectual functioning (Intelligence Quotient [IQ] 30-70; mean IQ 50) with most indi- 
viduals demonstrating moderate to severe forms and the results from these studies provide support for the observation of a unique cognitive phenotype for individuals with DS that is distinct from other individuals even with matched level of cognitive functioning. Patterson et al., [33] assessed IQ in DS patients and reported a decline in IQ across time.

In the present study, there was statistically significant difference between patients and controls regarding to serum Beta amyloid protein level, increased in DS patients more than control. This agreed with Mehta et al., [25] who repoted that $A \beta 40$ and $A \beta 42$ levels were higher in DS than controls due to over expression of APP gene in DS which leaDS to increases in plasma $A \beta 40$ and $A \beta 42$ levels before plaque formation in DS brain. Annus et al., [34]. Immunohistochemistry studies have shown that striatal plaques are predominantly, or entirely, composed of $A \beta 1-40$ and $A \beta 1-42$. Familial forms of AD and DS share overproduction of amyloid as the proposed mechanism of amyloid deposition, whereas decreased clearance might be more significant in sporadic AD. Zis et al., (2018) [35]resulted that DS subjects show higher plasma $A \beta 42$ and $A \beta 40$ levels compared to cognitively normal subjects without trisomy 21 .

In the present study, the patient groups, showed significant positive correlation between serum Beta amyloid protein level with increase in age (with increased age there is increase in serum Beta amyloid protein level). This agreed with Coppus et al., [36]results which shoedthat levels of A $\beta$ 1-40 but not $A \beta 1-42$, were significantly related to age at diagnosis of dementia. Nistor et al., (2007) [37] The data presented in the current study extenDS these previous findings and shows that insoluble $\mathrm{A} \beta$ increases with age in DS but at older ages $(>40$ years) than that reported for soluble $A \beta$ and reaches significantly higher levels than in normal aging but closer to levels reported in $\mathrm{AD}$.

But this disagreed with Head et al., [38] that denoted that the relationship of plasma $A \beta$ to age is not clear. Although plasma $\mathrm{A} \beta$ concentrations are higher in DS, it is not clear whether levels increase with age or actually decrease as peripheral $\mathrm{A} \beta$ is sequestered into plaques. Mehta et al., [25] results showed that there was a significant negative correlation between age and $A \beta 40 \& A \beta 42$ levels in DS patients. Jones et al., [39] resuls showed that neither $A \beta 1-40$ concentrations nor $A \beta 1-42$ concentrations were associated with age.

In the present study, in the patient group, showed no significant correlation between serum
Beta amyloid protein levels with IQ. This agreed with Mehta et al., [25] in second analysis assuming no effect between IQ and A $\beta$

But this disagreed with Hartley et al., [40] resulted that an increase in global amyloid- $\beta$ is related to the decreased cognitive function in these areas beyond normative aging. Mehta et al., (2007) [18] in first analysis assumed an effect between IQ and $\mathrm{A} \beta$

\section{Conclusion:}

- We concluded that serum Beta amyloid protein level was significantly higher in children and adolescents with Down syndrome in comparison with healthy controls.

-We also concluded that there was an increase in serum Beta amyloid protein level with increase age of children and adolescents with Down syndrome.

- There was no significant correlation between serum Beta amyloid protein level and IQ in patient with Down syndrome.

\section{Acknowledgments:}

This research was carried out without funding.

\section{Conflicts of interest:}

No conflicts of interest declared.

\section{Authors' contributions:}

All authors had equal role in design, work, statistical analysis and manuscript writing. All authors have approved the final article work.

\section{References}

1- PATTERSON D.: Molecular Genetic Analysis of Down Syndrome. J. Hum Genet., 126 (1): 195-214, 2009.

2- PANKAJ D.M., GEORGE C. and AMY J.: Increased Amyloid B Protein Level in Children and Adolescent of Down Syndrome. J. Neurol. Sci., 26: 22-7, 2007.

3- WEIJERMAN M.E. and De WINTER: Clinical Practice. The Care of Children with Down Syndrome. Eur. J. Pediatr., 169: 1445-52, 2010.

4- PRILLER C., BAUER T., MITTEREGGER G., KREBS B., KRETZSCHMAR H.A. and HERMS J.: Synapse Formation and Function is Modulated by the Amyloid Precursor Protein. J, Neurosci., 26 (27): 7212-21, 2006.

5- LI S., DENG J., HOU H., TIAN J., GIUNTA B., WANG Y., MORI T., et al.: Specific Antibody Binding to the APP672-699 Region Shifts APP Processing from A-to BCleavage. Cell Death Dis., 5 (8): 13-25, 2014.

6- VASSAR R., KOVACS D.M., YAN R. and WONG P.C.: The $\beta$-secretase Enzyme BACE in Health and Alzheimer's 
Disease Regulation, Cell Biology, Function, and Therapeutic Potential. J. Neurosci., 29 (41): 12787-94, 2009.

7- HILT S., TANG T., WALTON J.H., BUDAMAGUNTA M., MAEZAWA I., KÁLAI T., et al.: A Metal-Free Method for Producing MRI Contrast at Amyloid- $\beta$. J. Alzheimers Dis., 55 (4): 1667-81, 2017.

8- COPPUS A.M., SCHUUR M., VERGEER J., JANSSENS A.C.J., OOSTR B.A., VERBEEK M.M., et al.: Plasma P Amyloid and the Risk of Alzheimer's Disease in Down Syndrome. Neurobiol. Aging., 33 (9): 1988-94, 2012.

9- DORAN E., KEATOR D., HEAD E., PHELAN M.J., KIM R., TOTOIU M. and LOTT I.T.: Down Syndrome, Partial Trisomy 21, and Absence of Alzheimer's Disease: The Role of APP. J. Alzheimers. Dis., 56 (2): 459-70, 2017.

10- REITZ C., BRAYNE C. and MAYEUX R.: Epidemiology of Alzheimer Disease. Nat. Rev. Neurol., 7 (3): 137-42, 2011.

11- LOTT I.T. and HEAD E.: Alzheimer Disease and Down syndrome Factors in Pathogenesis. J. Neurobiol.-Aging., 26 (3): 383-9, 2005.

12- ZHANG Y.W., THOMPSON R., ZHANG H. and XU H.: APP Processing in Alzheimer's Disease. Mol. Brain, 4 (1): 3-28, 2011.

13- WEISSMILLER A.M. and WU C.: Current Advances in Using Neurotrophic Factors to Treat Neurodegenerative Disorders. Transl. Neurodegener. J., 1 (1): 14-36, 2012.

14- BALL S.L., HOLLAND A.J., HON J., HUPPERT F.A., TREPPNER P. and WATSON P.C.: Personality and Behaviour Changes Mark the Early Stages of Alzheimer's Disease in Adults with Down's Syndrome: Findings from a Prospective Population Based Study. Int.-J.-Geriatr.Psych., 21 (7): 661-73, 2006.

15- BARBIERO L., BENUSSI L. and GHIDONI R.: BACE2 is Overexpressed in Down's Syndrome. J. Exp. Neurol., 182: 335-45, 2003

16- YAO J., HO D., CALINGASAN N.Y., PIPALIA N.H., LIN M.T., BEAL M.F., et al.: Neuroprotection by Cyclodextrin in Cell and Mouse Models of Alzheimer Disease. J. Exp. Med., 209 (13): 2501-13, 2012.

17- KIRKPATRICK L.A. and FEENEY B.C.: A simple guide to IBM SPSS statistics for version 20.0. Student ed. Belmont, Calif.: WaDSworth, Cengage Learning; 2013.

18- DOECKE J.D., LAWS S.M., FAUX N.G., WILSON W., BURNHAM S.C., LAM C.P., et al.: Blood-Based Protein Biomarkers for Diagnosis of Alzheimer Disease. J. Arch.Neurol., 69 (10): 1318-25, 2012.

19- SHETTY S.K., NAIK N., KUMAR P.K. and HEGDE A.M.: Down Syndrome: A Literature Review. MedicoLegal Update, 13 (1): 64-80, 2013.

20- DOSIER L.B.M., VAUGHN B.V. and FAN Z.: Sleep Disorders in Childhood Neurogenetic Disorders. J. Child., 4 (9): 82-93, 2017.

21- STOLL C., DOTT B., ALEMBIK Y. and ROTH M.P.: Associated Congenital Anomalies Among Cases with Down Syndrome. Eur. J. Hum. Genet., 58 (12): 674-80, 2015.
22- ASIM A., KUMAR A., MUTHUSWAMY S., JAIN S and AGARWAL S.: "Down Syndrome: An Insight of the Disease." J. Biomed. Sci., 22 (1): 41-58, 2015.

23- MOCKETT B.G., RICHTER M., ABRAHAM W.C. and MÜLLER U.C.: Therapeutic Potential of Secreted Amyloid Precursor Protein APPs a. J. Front. Mol. Neurosci., 10: 30-41, 2017.

24- LEI X., LEI L., ZHANG Z. and CHENG Y.: Downregulated Mir-29c Correlates with Increased BACE1 Expression in Sporadic Alzheimer's Disease. Int. J. Clin. Exp. Pathol., 8 (2): 1565-83, 2015.

25- MEHTA P.D., CAPONE G., JEWELL A. and FREEDLAND R.L.: Increased Amyloid B Protein Levels in Children and Adolescents with Down Syndrome. J. Neurol. Sci., 254 (1-2): 22-7, 2007.

26- DIAMANDOPOULOS K. and GREEN J.: Down Syndrome: An Integrative Review. J. Neonatal. Nurs., 24 (5): 235-41, 2018.

27- HUSSAMY D.J., HERRERA C.L., TWICKLER D.M., MCINTIRE D.D. and DASHE J.S.: Number of Risk Factors in Down Syndrome Pregnancies. Am. J. Perinatol., 36 (1): 79-85, 2019.

28- McNERNEY M.W., MOBLEY W.C. and SALEHI A.: Down Syndrome or Trisomy 21. Neurosci. Biobehav. Rev., 42 (3): 2-15, 2017.

29- ANDERSEN A.M.N. and URHOJ S.K.: Is Advanced Paternal Age a Health Risk for the Offspring? Fertil Steril., 107 (2): 312-8, 2017.

30- RAMASAMY R., CHIBA K., BUTLER P. and LAMB D.J.: Male Biological Clock: A Critical Analysis of Advanced Paternal Age. Fertil Steril., 103 (6): 1402-6, 2015.

31- ZIGMAN W.B.: Atypical Aging in Down Syndrome. Dev. Disabil. Res. Rev., 18 (1): 51-67, 2013.

32- GRIECO J., PULSIFER M., SELIGSOHN K., SKOTKO B. and SCHWARTZ A.: Down Syndrome: Cognitive and Behavioral Functioning Across the Lifespan. Am. J. Med. Genet. C Semin. Med. Genet., 169 (2): 135-9, 2015.

33- PATTERSON T., RAPSEY C.M. and GLUE P.: Systematic Review of Cognitive Development Across Childhood in Down Syndrome: Implications for Treatment Interventions. J. Intellect Disabil., 57 (4): 306-18, 2013.

34- ANNUS T., WILSON L.R., HONG Y.T., ACOSTACABRONERO J., FRYER T.D., CARDENAS-BLANCO A. and MENON D.K.: The Pattern of Amyloid Accumulation in The Brains of Adults with Down Syndrome. Alzheimers Dement., 12 (5): 538-45, 2016.

35- ZIS P. and STRYDOM A.: Clinical Aspects and Biomarkers of Alzheimer's Disease in Down Syndrome. Free Radic. Biol. Med., 114: 3-9, 2018.

36- COPPUS A.M., SCHUUR M., VERGEER J., JANSSENS A.C.J., OOSTRA B.A., VERBEEK M.M., et al.: Plasma B Amyloid and the Risk of Alzheimer's Disease in Down Syndrome. Neurobiol. Aging., 33 (9): 1988-94, 2012.

37- NISTOR M., DON M., PAREKH M., SARSOZA F., GOODUS M., LOPEZ G.E., et al.: Alpha-and BetaSecretase Activity as a Function of Age and Beta-Amyloid 
in Down Syndrome and Normal Brain. Neurobiol. Aging., 28 (10): 1493-506, 2007.

38- HEAD E., DORAN E., NISTOR M., HILL M., SCHMITT

F.A., HAIER R.J., et al.: Plasma Amyloid-B as A Function of Age, Level of Intellectual Disability, and Presence of

Dementia in Down Syndrome. J. Alzheimers. Dis., 23

(3): 399-409, 2011.

39- JONES E.L., HANNEY M., FRANCIS P.T. and BAL-
LARD C.G.: Amyloid B Concentrations in Older People with Down Syndrome and Dementia. Neurosci. Lett., 451 (2): 162-4, 2009.

40- HARTLEY S.L., HANDEN B.L., DEVENNY D., MIHAILA I., HARDISON R., LAO P.J., et al.: Cognitive Decline and Brain Amyloid-B Accumulation Across 3 Years in Adults with Down Syndrome. Neurobiol. Aging., 58: 68-76, 2017.

\section{دراسة مستوى سلائف بروتين الآميلويل فى بلازما الآطفال والمراهقين الذين يعانون من متلازمة دين دالائ}

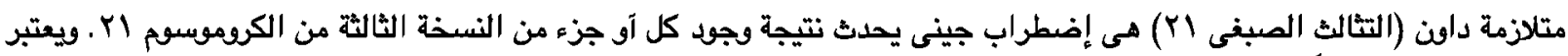

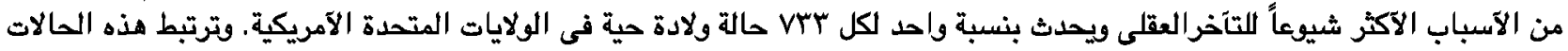

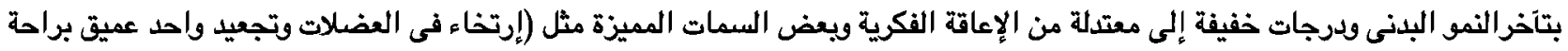

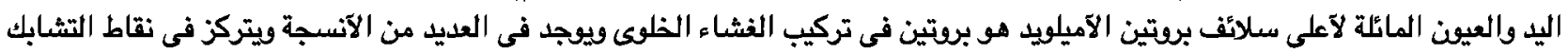

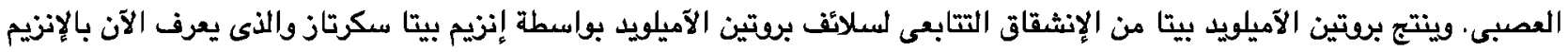

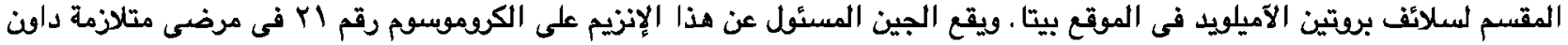
واللىى ريما يساهم في زيادة إنتاج بروتين الآميلويد.

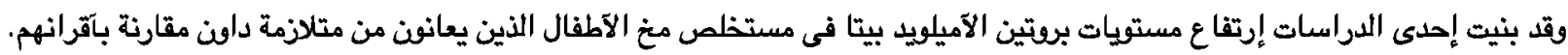

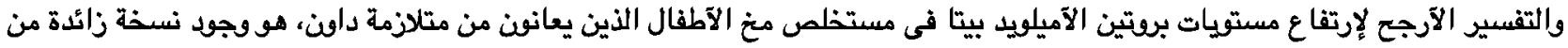

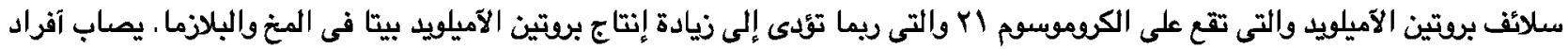

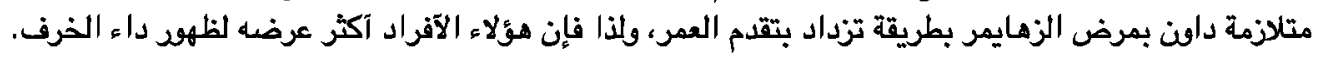

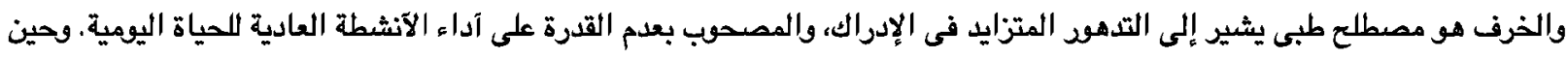

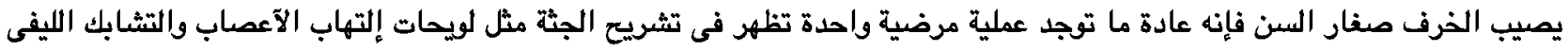

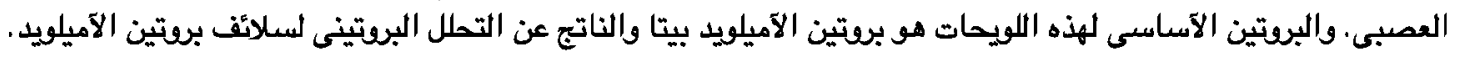

الهدف من الدراسةة: مقارنة مستوى بروتين الآميلويد بيتا لدى آطفال متلازمة داون مقارنة باتّرانهم والعلاقة بين مستوى الآميلويد بيتا

$$
\text { ومعدل الذكاء فى آفراد الدراسة. }
$$

طرق البحث: تم إجراء الدراسة على . ع طفل مصرى وقد تم تقسيمهم إلى مجموعتين:

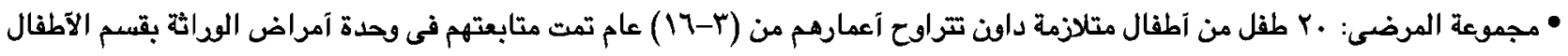
بمستشفى جامعة طنطا. • مجموعة المقارنة: . ب من الأطفال الآصحاء بتحليل وداثى سليم من نفس الجنس والسن. مدة الدراسة: حوالى با شهر. معايير الإشتمال: ا - آطفال يعانفن من متالازمة داون ويتم تاكيد ذلك بالك بالتحليل الوراثى.

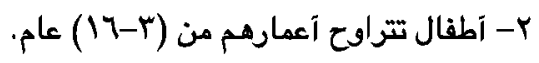
معايير الإستبعاد: ا - آطفال مصابين بآمراض وداثية آخرىى.

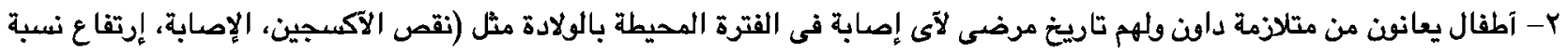

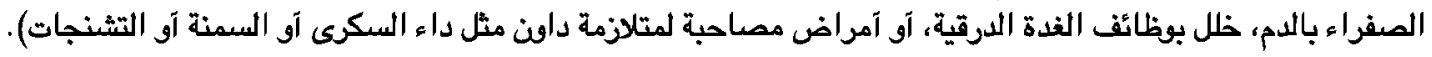


وقد خضع كل الآطفال من المجموعتين للآتى:

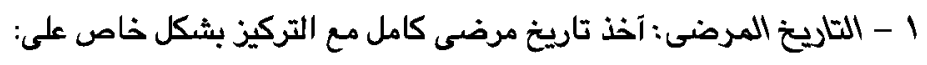

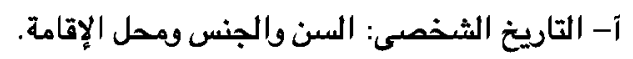

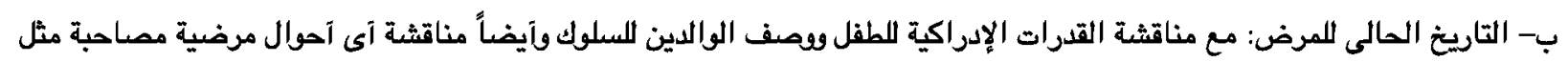

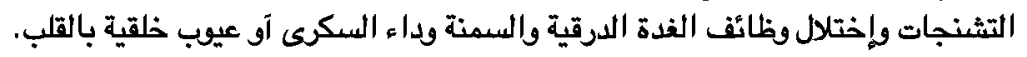

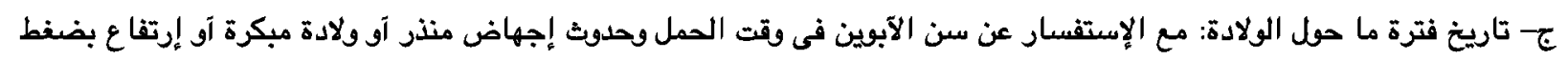

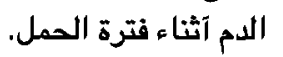

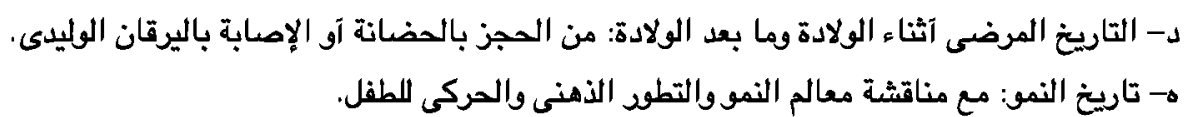

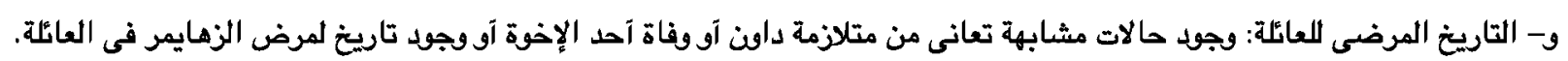
r- الفحص الطبى : فحص طبى شامل للحالة مع البحث عن السمات المميزة لمتلازمة دافن.

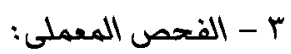
- تحليل وداثى.

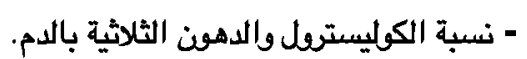

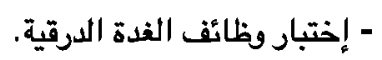

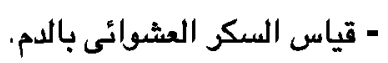
- الفحص المعملى موضع البحث: نسبة بروتين الآميلويد بيتا بالدم. - تم آخذ موافقة من كل آولياء آمود الآطفال الذين تم إجراء البحث عليهم. - تم البدء فى الدراسة بعد موافقة لجنة الآخلاقيات بكلية الطب جامعة طنطا. 